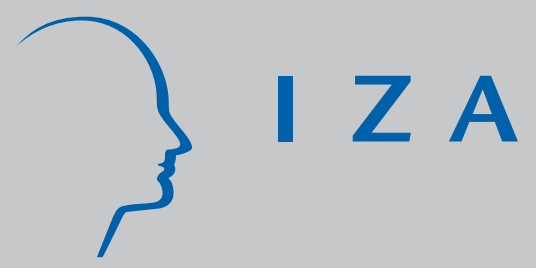

IZA DP No. 1067

Did European Labor Markets Become

More Competitive in the 1990s?

Evidence from Estimated Worker Rents

Gilles Saint-Paul

March 2004 


\title{
Did European Labor Markets Become More Competitive in the 1990s? Evidence from Estimated Worker Rents
}

\author{
Gilles Saint-Paul \\ GREMAQ-IDEI, Université de Toulouse I, \\ CEPR and IZA Bonn
}

Discussion Paper No. 1067

March 2004

\author{
IZA \\ P.O. Box 7240 \\ 53072 Bonn \\ Germany \\ Phone: +49-228-3894-0 \\ Fax: +49-228-3894-180 \\ Email: iza@iza.org
}

\begin{abstract}
Any opinions expressed here are those of the author(s) and not those of the institute. Research disseminated by IZA may include views on policy, but the institute itself takes no institutional policy positions.
\end{abstract}

The Institute for the Study of Labor (IZA) in Bonn is a local and virtual international research center and a place of communication between science, politics and business. IZA is an independent nonprofit company supported by Deutsche Post World Net. The center is associated with the University of Bonn and offers a stimulating research environment through its research networks, research support, and visitors and doctoral programs. IZA engages in (i) original and internationally competitive research in all fields of labor economics, (ii) development of policy concepts, and (iii) dissemination of research results and concepts to the interested public.

IZA Discussion Papers often represent preliminary work and are circulated to encourage discussion. Citation of such a paper should account for its provisional character. A revised version may be available on the IZA website (www.iza.org) or directly from the author. 
IZA Discussion Paper No. 1067

March 2004

\section{ABSTRACT}

\section{Did European Labor Markets Become More Competitive in the 1990s? Evidence from Estimated Worker Rents*}

This paper analyses the evolution of quantitative measures of employee rents in Europe during the nineties, using the European Household Panel Survey. One looks at two class of measures: wage differentials between workers along industry and firm size dimensions, and estimated welfare differences between employed and unemployed using a model of labor market transitions. The results are largely negative; there is robust evidence of falling rents during that period only in Ireland.

JEL Classification: D3, E24, J3

Keywords: unemployment, insiders, rents, labour market flexibility

Gilles Saint-Paul

GREMAQ-IDEI

Université des Sciences Sociales

Manufacture des Tabacs

Allée de Brienne

31000 Toulouse

France

Email: gilles.saint-paul@univ-tlse1.fr

\footnotetext{
* This paper was prepared for the Annual Bank of Chile Conference, Santiago, November 2003. It has benefitted from financial support from the European Union under the DAEUP project. I thank AnneLaure Mascle-Allemand for excellent research assistance, and to Pietro Ichino for helping me with the evolution of unemployment benefits in Italy.
} 


\section{Introduction}

In many European countries unemployment has been very high for almost three decades. Many economists have ascribed the problem to lack of competition in labor markets plagued by institutional rigidities, such as employment protection, generous unemployment benefits, compression in relative wages due to collective bargaining, and so on. On the other hand, few countries have removed these rigidities. Instead, governments have developed a lot of (often very costly) policies with dubious effects, such as permanent budget deficits, relief jobs in the public sector that did little to enhance the longterm unemployed job prospects, and "voodoo" economics such as working time reduction. However, some marginal reforms have been implemented, which may have had an effect. One example is the liberalization of temporary contracts in Spain and other countries in the eighties and nineties. Another is a recent reform of the French unemployment benefit system which tightly monitors their job search. If one looks in detail at the history of labor market reforms in a given European country, one finds the following characteristics. First, reforms are pretty numerous and amount to an accumulation of small changes. Second, some reforms tend to increrase labor market flexibility, while others tend to reduce it. Third, for each individual reform it is quite difficult to assess the magnitude of its impact.

Furthermore, the degree of labor market competition may also be affected by other developments such as increases in product market competition due to deregulation or greater openness to international trade. One may even hope that such changes will help reduce European unemployment and thus - although groups which benefit from labor rigidities also have an interest in blocking these changes - spare painful reforms of the labor market ${ }^{1}$. Thus we might observe increases in labor market competition even in the absence of labor market reforms.

This discussion suggests that rather than looking directly at policy mea-

\footnotetext{
${ }^{1}$ See Blanchard and Philippon (2003), for an analysis.
} 
sures it may be useful to look at the evolution of some quantitative measures of labor market competition. It is what I try to do in this paper. I look at the evolution of two very different measures of labor market competition in a number of European countries between 1994 and 2000. The first measure captures inter-industry differences in wages, while the second is a proxy for the welfare difference, in present discounted value terms, between the employed and the unemployed.

\section{Rents and their meaning}

We define the "rent" of an employed worker as the present discounted value of his expected flow of future incomes, minus the present discounted value of the income flow of an unemployed worker with similar characteristics.

Why are we interested in such a measure? Because it tells us how uncompetitive the labor market is. In a perfectly competitive labor market, the unemployed would be able to underbid the employed up to the point where people would be indifferent between being employed or unemployed. That may mean full employment, in which case an unemployed would immediately find a job, so that his situation would in effect be no different from that of an employed, or it may mean that the wage has fallen to the level of unemployment benefits (adjusted for the disutility of effort), in which case there is "voluntary" unemployment in the sense that the unemployed are in fact indifferent about getting a job.

The rent also tells you how much you lose when you lose your job. In a no-rent society the "risk" of job loss is not a risk. People are insured against it by the perfectly competitive labor market which makes them indifferent between working and not working. All the implications of job loss being painful derive from the facts that employed workers have rents.

Where do rents come from? They may come from microeconomic frictions which prevent the labor market from being competitive. The theoretical lit- 
erature has identified a number of channels. The efficiency wage theory ${ }^{2}$, for example, states that it is costly for firms to monitor their workers' effort level. Consequently, they prefer to pay above-market clearing wages so as to deter shirking. This theory implies that the rent will be higher, the more severe the informational problems in observing effort. The insider-outsider theory ${ }^{3}$ tells us that firms have sunk specific investments in locating and training workers, which generates a hold-up problem. Once the investment is paid for, the worker can expropriate part of it by asking above-market clearing wages. This theory predicts that the rent is larger, the more important are ex-ante specific investments in a given job ${ }^{4}$. It also predicts that the rent is larger, the greater the worker's "bargaining power", i.e. the share of the total surplus that he is able to appropriate - although there is no straightforward empirical equivalent of that parameter. The search and matching theory ${ }^{5}$ extends the insider-outsider theory to a general equilibrium framework where there is a per-unit-of-time cost of maintaining a vacancy and the rate at which they are filled depends on the ratio between the stock of unemployment and the stock of vacancies. The tighter the labor market, the longer it takes to fill a vacancy, the larger the sunk hiring cost, and the greater the rent; the theory hence predicts that there is a positive relationship between the rent and labor market tightness. It also predicts that the rent is larger, the greater the cost of vacancies and the less efficient the process of matching between workers and firms. Finally, union wage-setting models directly generate rents as unions act as monopolies in the labor market.

All these models also predict that a number of labor market regulations will affect the rent. Firing costs will increase the rent under any of these models; in the efficiency wage model, it makes it more costly to dismiss workers when they have been caught shirking, thus raising the rent that

\footnotetext{
${ }^{2}$ See Shapiro and Stiglitz (1984), Solow (1979), Schlicht (1978).

${ }^{3}$ See Lindbeck and Snower (1988), Blanchard and Summers (1986), Layard et al (1990).

${ }^{4}$ The macroeconomic consequences of the degree of specificity in investments are explored by Caballero and Hammour (1998).

${ }^{5}$ See for example Mortensen and Pissarides (1994).
} 
must be paid to deter it. In the insider-outsider model, it acts as a sunk cost, as it must be paid to get rid of the worker in order to replace him with another one. Minimum wages directly increase the rent for those employed workers for whom they are binding. Work rules may also increase rents to the extent that they impose specific investments on firms and more generally reduce competition between workers.

It is also true that product market regulation affects rents. By increasing monopoly power, they increase a firm's total revenue per worker; the rent is increased as long as the workers have some ability to seize part of that revenue. Under union wage-setting models, workers' rents are linked to product market competition via a simple law of derived demand. A more regulated product market implies a lower price-elasticity of demand for each firm, which in turn implies a lower wage-elasticity of labor demand, and thus a higher wage.

We now briefly discuss the political consequences of rents ${ }^{6}$. Let us now go back to the observation made above, that rents tell you how much you lose when you lose your job. It implies that in an economy with rents, there will be a general aversion to job loss, more so, the greater the rent. Therefore, incumbent employees will tend to oppose policies that threaten their jobs and to promote policies that protect them. That incentive would be absent in an economy without rents. If rents differ among workers, they want to support different policies, with workers with greater rents in favor of more protection.

This implies that greater rents increase the support for employment protection legislation. Since we have seen that employment protection itself also tends to increase rents, we have a mutual feedback there. Beyond that, any shift that tends to increase rents should enhance the support for employment protection. Thus, following the above arguments, we expect a greater political support for employment protection after a hike in the minimum wage, after a period of tight labor markets, or after any technological or organi-

\footnotetext{
${ }^{6}$ See Saint-Paul $(1997,2000,2002)$ for an analytical treatment.
} 
zational change that would reduce a firm's ability to monitor workers or its required specific investment in a job.

Rents also easily generate politico-economic complementarities between different labor market institutions. By a politico-economic complementarity between institution $\mathrm{A}$ and institution $\mathrm{B}$, I mean that the political support for institution $\mathrm{A}$ is greater if institution $\mathrm{B}$ is in place, and vice-versa. As I just argued, institutions that create (or increase) rents increase the political support for employment protection. But employment protection itself increases the political support from employed workers for institutions that create rents, because it reduces their exposure to unemployment and thus their prospects of losing the rent. Politico-economic complementarities imply that a comprehensive labor market reform will have more support than a piece-meal approach.

While rents increase the support for institutions that directly increase employment protection, they also have a pervasive effect on the way people view most policy changes. When the rent is high, incumbent employees have a vested interest in opposing policies that threaten their jobs. This means that any policy change which implies some labor reallocation will face greater political opposition in economies with higher rents ${ }^{7}$. This applies to trade liberalization, changes in the level and structure of government spending, and so on. In other words, rents tend to generate a bias in favor of the status quo in virtually any policy area.

The story of labor market flexibility in Europe in the 1990s is very much that of a half-full, half-empty bottle; measures that have increased labor flexibility have alternated with measures that have reduced it. Thus, from that account we do not necessarily expect rents to fall; however, their evolution in a given country may tell us which reforms have had the stronger effects. On the other hands, greater trade integration and deregulation in product markets is a clear trend. It should push rents downwards and if it has a large enough effect on labor markets we should observe falling rents.

\footnotetext{
${ }^{7}$ See Saint-Paul (1996a).
} 


\section{Measuring competition in European Labor markets}

There are various ways to assess whether or not European labor markets are becoming more competitive. One possibility is to construct indices of labor market regulation and look at their evolution over time in different countries. Such an approach has been mostly pioneered by the OECD ${ }^{8}$. The reliability of these indices depend on how quantitative the underlying variables are, and how reliable is the researcher's assessment of the importance of a given change in regulation. In some cases, it is easy to construct an index because the regulation being measured has a clear quantitative definition. This is the case, for example, for unemployment benefits, where one has constructed fairly reliable indices of replacement rations. However, even in such a case, the index is not fully accurate as it fails to capture the diversity of individual situations and the way the unemployment benefit system is actually administered. Constructing indices of more qualitative regulations such as employment protection is obviously even more complicated. These indices do well in cross-sectional comparisons but are more problematic for assessing evolutions over time ${ }^{9}$. For example, in the nineties many countries have moved back and forth in the liberalization of temporary contracts, and sometimes this has been accompanied by moves in the opposite direction concerning the degree of protection of permanent contracts. It is not easy to determine whether employment protection goes up or down if a reform makes it harder to use temporary contracts but at the same time eases the conditions under which a permanent worker may be dismissed.

Thus, it is useful to pursue a different approach, and try to look at direct quantitative indicators of worker's rents. The drawback of that approach is that it does not tell us which reforms have been implemented; workers' rents may fall under a number of labor market reforms, product market reforms

\footnotetext{
${ }^{8}$ Typical is Grubb and Wells (1993) and the OECD's Job Study (1994).

${ }^{9}$ Indeed, such indices as the Bertola (1990) one, are typically used for cross-sectional studies.
} 
or the sheer pressure of international competition. On the other hand, it gives us an idea of the evolution of the true degree of competition in labor markets. It avoids misclassifying a policy change or taking serious one which turns out to have only second-order effects on actual labor market flexibility, or which, for some reason, is not enforced.

To measure rents, we use two different approaches, that are described in detail in the next two sections.

\section{The inter-industry approach}

The first one exploits variation across industries of wages. This empirical regularity has been much studied in the eighties and nineties, under the impulse of Krueger and Summers (1988). In particular, and that is most useful for our purposes, the literature has shown that these differentials are not associated with compensating differentials for working conditions or nonwage benefits, nor with unobservable worker heterogeneity. On the other hand, they are correlated with a number of industry characteristics such as union density, capital intensity, product market competition, and so on, that are likely to be associated with the rent that can be extracted by workers and their power to do so. In other words, there is a strong presumption that differences in wages between industries are differences in rents rather than anything else. Therefore, we hope to learn something about the evolution over time of labor market rents in a number of European countries by looking at how the estimated coefficients of a wage equation, in an individual data set, on industry dummies evolve. If rents are falling over time, then we expect the dispersion in these coefficients across sectors to be falling too: In a rent-free economy, all of them would be equal to zero. Assuming that the least-paying sector is more or less perfectly competitive, we can also define an average rent by looking at the employment-weighted average of the difference between a sector's coefficient and that of the least-paying sector. That alternative measure allows to capture changes in the rent that are due to 
labor reallocation from high-rent to low-rent sectors, whereas the dispersion measure gives us an idea of the evolution of the rent, in a given sector.

The data we use is the European Household Panel Survey. The advantage is that it has data on wages, individual characteristics and labor market status, that are consistent across countries, and available for all EU members. Its panel dimension allows to control for unobserved heterogeneity among individuals by making use of fixed-effect estimators. The drawback is that it has fewer observations than a typical national labour force survey, and that data for Germany and the UK are not available after 1994.

We estimate wage equations for each of the countries. Each observation is an individual at a given date, and the specification is

$$
\begin{aligned}
\ln w_{i t}= & b_{0} E D 3_{i t}+b_{1} E D 2_{i t}+b_{2} A G E_{i t}+b_{3} A G E_{i t}^{2}+b_{4} M A R R I E D \\
& +b_{5} S E X_{i t}+\sum_{s=2}^{T} \sum_{k=1}^{N} c_{k s}\left(I D_{i t}^{k} * T D_{i t}^{s}\right)+\sum_{k=2}^{N} c_{k 1}\left(I D_{i t}^{k} * T D_{i t}^{1}\right)+c_{0}
\end{aligned}
$$

where

$T D^{s}=$ Time dummy for date $s \cdot T D_{i t}^{s}=1$ if $t=s, 0$ if not.

$I D^{k}=$ Industry dummy for industry $k . I D_{i t}^{k}=1$ if individual $i$ works in industry $k$ at date $t, 0$ if not.

$T=$ Number of periods,

and other variables are self-explanatory.

The above equation can be estimated without and with individual fixed effects. The fixed effects allow to eliminate potential bias sources like unobserved heterogeneity among workers. If workers with greater unobserved ability are more likely to work in certain industries, part of the industry dummy reflects the return to unobserved ability rather than a rent. The earlier literature has found that inter-industry wage differentials are typically robust to the introduction of individual fixed effects, although somewhat smaller. ${ }^{10}$

\footnotetext{
${ }^{10}$ See Saint-Paul (1996b), ch.5 for a survey.
} 
We can then construct synthetic indicators of labor market rents.

We first define the "spread" indicator for any date $s$, as

$$
S P R E A D_{s}=\max _{k} c_{k s}-\min _{k} c_{k s} .
$$

It tells us the difference in wages between the best-paying and the worstpaying sector, for similar workers. If the worst-paying sector is interpreted as perfectly competitive, then it is a measure of the highest rent paid to workers in that economy, irrespective of the number of workers who earn the rent. ${ }^{11}$ Therefore, it would fail to capture a reduction in rents due to a fall in the employment share of the best-paying sectors. Therefore, we also compute an "average rent indicator" for date $s$ as

$$
A R E N T_{s}=\frac{\sum_{k=1}^{N} n_{k s}\left(c_{k s}-\min _{j} c_{j s}\right)}{\sum_{k=1}^{N} n_{k s}},
$$

where $n_{k s}=$ number of employed in industry $k$ at date $s$, and $c_{j k N}=0$ by extension. $^{12}$

This is a measure of the average rent earned by a worker in that economy, as compared to the least-paying sector. If that sector is competitive, it also gives us an idea of the welfare difference, in annuity terms, between an employed and an unemployed.

Once these indicators are constructed, we look at their evolution over time in each country. One shortcoming with the data used is that they are only available for 7 consecutive years ( 3 for the UK and Germany). One would like a longer time series dimension in order to look at the long-run evolution of rents.

We shall also perform another exercise, namely look at wage differentials across size categories of firms rather than industries, using the same methodology.

\footnotetext{
${ }^{11}$ For date $s=1$ the formula is slightly different:

$S P R E A D_{1}=\max \left(\max _{k} c_{k 1}, 0\right)-\min \left(\min _{k} c_{k 1}, 0\right)$.

${ }^{12}$ For $s=1$ the formula is again slightly different:

$A R E N T_{s}=\frac{\sum_{k=1}^{N} n_{k s}\left(c_{k s}-\min \left(\min _{j} c_{j s}, 0\right)\right)}{\sum_{k=1}^{N} n_{k s}}$
} 


\section{The transition approach}

The second approach, in the spirit of Cohen (1999), tries to estimate a dynamic process for individual transitions between employment and unemployment, and to use the estimated coefficients to compute the present discounted value of being employed and the present discounted value of being unemployed for any given category of worker. The difference between the two gives us the total rent of the employed.

Assume that for a given category of individuals, they move between two states, employed and unemployed. The transition rate from employment to unemployment is $s$; the transition rate from unemployment to employment is $h$. The income in unemployment is $b$ and the income in employment is $w$. The real interest rate is $r$. Workers are risk-neutral.

Then, the evolution equation for the value of being employed $V_{e}$, if defined as the expected present discounted value of income flows when employed is:

$$
r V_{e}=w+s\left(V_{u}-V_{e}\right)+\dot{V}_{e}
$$

Similarly, the evolution equation for the value of being unemployed $V_{u}$ is

$$
r V_{u}=b+h\left(V_{e}-V_{u}\right)+\dot{V}_{u}
$$

In steady state, the total rent defined as the difference between the utility of the employed and that of the unemployed is, i.e. by $Q=V_{e}-V_{u}$ is

$$
Q=\frac{w-b}{r+s+h}
$$

Another concept of interest is the cost per unit of time to the employer of having to pay the rent $Q$ in addition to the worker's alternative wage. It is given by the annuity equivalent of the rent $Q$, i.e. $q=(r+s) Q$ :

$$
q=\frac{(r+s)(w-b)}{r+s+h}
$$

While the total rent $Q$ is measured in terms of workers' welfare, the annuity rent $q$ expresses the same concept from the point of view of the 
firm's labor cost. The rent $q$ tells us how much firms have to pay workers per unit of time in addition to their alternative wage $r V_{u}: q=w-r V_{u}$. The two differ from each other because welfare can be transferred to workers not only in the form of wages but in the form of job security. The rent $q$ goes up with $s$, because a higher job loss rate reduces the unemployed's welfare. It goes down with $h$ for the opposite reason. In contrast, $Q$ falls with $s$, because everything else equal, the employed workers are worse-off when their jobs are insecure. Nevertheless, the gap between their wage and their alternative wage goes up.

In principle, if we can estimate transition rates between employment and unemployment, as well as the income of the employed and the unemployed, we can compute $Q$ and $q$.

The most important shortcoming with that approach is that if $w, b, s$, and $h$ have different cyclical elasticities, variations in $q$ and $Q$ over a period of a few years are as likely to result from the influence of business cycles as that of underlying changes in the degree of labor market competition. In order to control for that we pool all the countries together and impose a common response of these variables to country-specific business cycle conditions. This leads to the following specification.

$$
\begin{aligned}
Y_{i t}= & \sum_{j=1}^{P}\left(C D_{i t}^{j} *\left(a_{j 0}+a_{j 1} * S B_{i t}\right)+\right. \\
& \sum_{j=1}^{P}\left(b_{0}^{j} E D 3_{i t}+b_{1}^{j} E D 2_{i t}+b_{2}^{j} A G E_{i t}+b_{3}^{j} A G E_{i t}^{2}+b_{4}^{j} M A R R I E D+b_{5}^{j} S E X_{i t}\right) * C D_{i t}^{j} \\
& +\left(c_{0} U_{i t}+c_{1} U_{i t-1}+c_{2} \ln G D P_{i t}\right)
\end{aligned}
$$

where $Y_{i t}$ is one of the four variables of interest, $w, b, s$, and $h^{13}, P$ the number of countries, and there are three blocks. The first block captures the country-specific evolution of $Y$ over time. The second block captures the effect of individual characteristics, assuming country-specific responses. The

\footnotetext{
${ }^{13}$ See below for their specific definition.
} 
third block captures the effect of the business cycle: $U_{i t}$ is the unemployment rate in the country where the individual observation is located, while $G D P_{i t}$ is its real GDP. The coefficients are assumed common across countries, which allows identification. The "structural break" dummies $S B_{i t}$ are defined by

$$
\begin{aligned}
& S B_{i t}=0 \text { if } t \leq t_{0} \\
& S B_{i t}=1 \text { if } t>t_{0}
\end{aligned}
$$

They allow to compute the country-specific change in $w, b, s$, and $h$ between the two subperiods defined by (3).

The second shortcoming is that it turns out to be difficult to get reliable estimates of $b$, the unemployment benefit payments, from the data. The problem is that the data base is silent about the flow of unemployment benefits payments. Rather, unemployment benefits payments are reported for the whole year and there appears to be a lag between unemployment spells and the actual payment of corresponding benefits. My attempts at solving it using econometric methods have failed in that they yield estimates for $\Delta b$ that are not plausible for many countries and that no not match the evolution over time of unemployment benefits replacement ratios as estimated by the OECD.

Therefore, we use equation (2) only for estimating $\Delta w, \Delta s$, and $\Delta h$. The three variables of interest are defined as follows:

$-\ln w_{i t}$, the log of individual earnings for an employed, in which case the regression is estimated using only observations such that the individual is employed at $t$. (Regression 1)

$-E D_{i t}$, a dummy equal to 1 if the individual is employed at $t$, in which case the regression uses only observations such that the individual were unemployed at $t-1$. (Regression 3$)$

$-U D_{i t}$, a dummy equal to 1 if the individual is unemployed at $t$, in which case the regression uses only observations such that the individual were employed at $t-1$. (Regression 4$)$

The coefficient $a_{j 1}$ gives us the change in the relevant variable between 
the two subperiods.

As for $\Delta b$,we use estimates of the benefit replacement ratio $\rho=b / w$ in the first subperiod as reported by Nickell (2003, Table 4$)^{14}$.

For any country, this allows to compute the average change in the total rent:

$$
\Delta Q / Q \approx \frac{w}{w-b} \Delta \ln w-\frac{b}{w-b} \Delta \ln b-\frac{\Delta h}{r+s+h}-\frac{\Delta s}{r+s+h} .
$$

Or,equivalently:

$$
\Delta Q / Q \approx \Delta \ln w-\frac{\rho \Delta \ln \rho}{1-\rho}-\frac{\Delta h}{r+s+h}-\frac{\Delta s}{r+s+h} .
$$

This number is computed using the average unconditional values of $w, b, h$, and $s$ in the first subsample $(t=1, \ldots S)$ and $r=0.03$. Similarly, we can compute the change in the rent in annuity terms:

$$
\Delta q / q \approx \Delta \ln w-\frac{\rho \Delta \ln \rho}{1-\rho}-\frac{\Delta h}{r+s+h}+\frac{h \Delta s}{(r+s+h)(r+s)}
$$

\section{Results}

\subsection{I: The inter-industry approach}

The estimated industry coefficients are highly significant and typically range up to $50-60 \% .{ }^{15}$ In some cases the number of observations is too low in a given time $\times$ country $\times$ industry cell and the coefficient cannot be used. For these reasons, I have dropped Luxembourg, Greece, and years 1999 and 2000 for Belgium. Also, the Panel stops in 1996 for Germany and the UK, starts in 1995 for Austria, and in 1996 for Finland.

\footnotetext{
${ }^{14}$ One problem with that study, is that its estimate of the replacement ratio for Italy in the second sub-period is unreliable. A discussion by the author with Pietro Ichino suggests progressive move toward a replacement ratio of 0.4 in the second subperiod, starting in 1997 , and a value of 0.26 in the first one, while estimating a version of (2) yields an increase in $\Delta \ln \rho$ by just 0.02 between the two subperiods. As a reasonable compromise, we shall take $\rho=(0.26+0.4) / 2=0.33$ in the second subperiod.

${ }^{15}$ They are reported in an appendix available from the author upon request.
} 
The following tables report the main statistics of interest, i.e. the two rent indicators $S P R E A D$ and $A R E N T$. Note that there probably is an aberrant observation for the Netherlands in 1998, due to a sharp drop in the estimated industry dummy coefficient for textiles.

\begin{tabular}{llllllll}
\hline \hline Country/Yr & 94 & 95 & 96 & 97 & 98 & 99 & 2000 \\
\hline Germany & 0.53 & 0.43 & 0.43 & & & & \\
Denmark & 0.27 & 0.31 & 0.26 & 0.17 & 0.33 & 0.31 & 0.26 \\
Netherlands & 0.33 & 0.32 & 0.33 & 0.30 & 0.63 & 0.46 & 0.42 \\
Belgium & 0.24 & 0.20 & 0.26 & 0.23 & 0.23 & & \\
France & 0.45 & 0.40 & 0.41 & 0.37 & 0.42 & 0.38 & 0.45 \\
United Kingdom & 0.66 & 0.57 & 0.62 & & & & \\
Ireland & 0.67 & 0.61 & 0.57 & 0.59 & 0.79 & 0.56 & 0.70 \\
Italy & 0.47 & 0.35 & 0.44 & 0.36 & 0.40 & 0.42 & 0.41 \\
Spain & 0.55 & 0.54 & 0.54 & 0.56 & 0.55 & 0.56 & 0.6 \\
Portugal & 0.49 & 0.54 & 0.51 & 0.58 & 0.50 & 0.53 & 0.53 \\
Austria & & 0.59 & 0.55 & 0.4 & 0.46 & 0.42 & 0.37 \\
Finland & & & 0.24 & 0.23 & 0.23 & 0.25 & 0.35 \\
\hline Tabla
\end{tabular}

Table 1 - Evolution of SPREAD.

In all countries, the $S P R E A D$ measure of rents fluctuates, but does not seem to follow any clear trend. In other words, the rents of the bestpaid workers relative to their characteristics does not seem to vanish. The exceptions are Austria, where rents seem to go down, and Finland and the Netherlands, where they go up. Overall, the results confirm the findings by Krueger and Summers that inter-industry wage differentials are quite persistent over time.

We now turn to the ARENT measure, reported in the next Table: 


\begin{tabular}{llllllll}
\hline \hline Country/Yr & 94 & 95 & 96 & 97 & 98 & 99 & 2000 \\
\hline Germany & 0.32 & 0.29 & 0.26 & & & & \\
Denmark & 0.17 & 0.14 & 0.18 & 0.09 & 0.2 & 0.21 & 0.15 \\
Netherlands & 0.15 & 0.21 & 0.19 & 0.13 & 0.45 & 0.22 & 0.17 \\
Belgium & 0.12 & 0.08 & 0.17 & 0.13 & 0.13 & & \\
France & 0.23 & 0.18 & 0.2 & 0.16 & 0.22 & 0.18 & 0.21 \\
United Kingdom & 0.4 & 0.31 & 0.32 & & & & \\
Ireland & 0.47 & 0.40 & 0.37 & 0.38 & 0.45 & 0.41 & 0.5 \\
Italy & 0.2 & 0.18 & 0.2 & 0.19 & 0.18 & 0.2 & 0.17 \\
Spain & 0.24 & 0.2 & 0.19 & 0.2 & 0.22 & 0.21 & 0.23 \\
Portugal & 0.14 & 0.15 & 0.15 & 0.18 & 0.14 & 0.15 & 0.16 \\
Austria & & 0.47 & 0.36 & 0.3 & 0.35 & 0.34 & 0.26 \\
Finland & & & 0.16 & 0.16 & 0.14 & 0.18 & 0.27 \\
\hline \hline Taber
\end{tabular}

Table 2 - Evolution of ARENT.

As table 2 shows, in most countries there is no clear upward or downward trend for the estimated average rent. In the cases of Spain or Italy, it is remarkably stable. Again, the rent seems to have gone down in Austria, and to have gone up in Finland ${ }^{16}$.

An issue is that the results may be driven by sectors where there are too few observations, implying a potentially volatile associated coefficient. To check for that, I have constructed alternative estimates of ARENT and $S P R E A D$ where only sectors with more than 100 observations in wave 1 are used. This implies that those variables are defined using a different set of industries in different countries, but that is unimportant as we do not compare the average level of the rent across countries. The results for $A R E N T$ are reported in Table 3 for ARENT and are slightly different from those of Table 2. Rents now seem to go down in Ireland and perhaps France and Italy, and to go up perhaps in Finland again, with no clear pattern elsewhere. In particular, they no longer seem falling in Austria.

\footnotetext{
${ }^{16}$ One shortcoming is that the results are substantially driven by the differences between the agricultural sector and other sectors, as the former pays substantially less. This need not be a problem; it may well be, for example, that the agricultural sector pays no rent at all - people are indifferent between working in that sector and being unemployed - while all other sectors pay rents that are similar. However, it is interesting to see how the results are changed when one drops the agricultural sector when computing the rent indicators. This is what we have done, and no clear pattern emerges.
} 


\begin{tabular}{llllllll}
\hline \hline Country/Yr & 94 & 95 & 96 & 97 & 98 & 99 & 2000 \\
\hline Germany & 0.13 & 0.11 & 0.11 & & & & \\
Denmark & 0.06 & 0.06 & 0.07 & 0.05 & 0.06 & 0.06 & 0.06 \\
Netherlands & 0.08 & 0.06 & 0.06 & 0.06 & 0.12 & 0.05 & 0.08 \\
Belgium & 0.06 & 0.08 & 0.08 & 0.09 & 0.07 & 0.12 & 0.05 \\
France & 0.24 & 0.16 & 0.16 & 0.15 & 0.19 & 0.19 & 0.18 \\
United Kingdom & 0.22 & 0.25 & 0.2 & & & & \\
Ireland & 0.2 & 0.23 & 0.14 & 0.15 & 0.13 & 0.11 & 0.11 \\
Italy & 0.2 & 0.17 & 0.2 & 0.18 & 0.18 & 0.19 & 0.17 \\
Spain & 0.23 & 0.19 & 0.18 & 0.19 & 0.21 & 0.2 & 0.22 \\
Portugal & 0.12 & 0.13 & 0.12 & 0.15 & 0.12 & 0.13 & 0.14 \\
Austria & & 0.06 & 0.04 & 0.04 & 0.04 & 0.07 & 0.07 \\
Finland & & & 0.04 & 0.03 & 0.04 & 0.04 & 0.09 \\
\hline \hline Table 3- & & & &
\end{tabular}

Table 3 - Evolution of ARENT, robust definition.

The usual problem of unobserved heterogeneity among workers also applies. For this reason, I have also computed the fixed effect estimator. One problem, though, is that if people do not move much between industries, in such a panel with relatively few periods and observations, the fixed effects are likely to be highly colinear with the vectors of industry dummies. Thus, the following results have to be taken with caution.

\begin{tabular}{llllllll}
\hline \hline Country/Yr & 94 & 95 & 96 & 97 & 98 & 99 & 2000 \\
\hline Germany & 0.31 & 0.35 & 0.38 & & & & \\
Denmark & 0.3 & 0.41 & 0.28 & 0.32 & 0.41 & 0.31 & 0.26 \\
Netherlands & 0.37 & 0.23 & 0.43 & 0.31 & 0.73 & 0.54 & 0.55 \\
Belgium & 0.15 & 0.11 & 0.24 & 0.13 & 0.19 & & \\
France & 0.29 & 0.25 & 0.32 & 0.24 & 0.32 & 0.27 & 0.28 \\
United Kingdom & 0.65 & 0.41 & 0.38 & & & & \\
Ireland & 0.49 & 0.40 & 0.35 & 0.36 & 0.66 & 0.56 & 0.60 \\
Italy & 0.3 & 0.19 & 0.28 & 0.18 & 0.26 & 0.27 & 0.26 \\
Spain & 0.4 & 0.16 & 0.12 & 0.24 & 0.18 & 0.30 & 0.32 \\
Portugal & 0.13 & 0.1 & 0.17 & 0.13 & 0.12 & 0.16 & 0.18 \\
Austria & & 0.39 & 0.28 & 0.2 & 0.27 & 0.26 & 0.11 \\
Finland & & & 0.28 & 0.22 & 0.26 & 0.20 & 0.17 \\
\hline \hline Tabla
\end{tabular}

Table 4 - Evolution of SPREAD, fixed effects.

As we see from Table 4, the estimated spread is quite volatile. Neverthe- 
less, there is still evidence of a downward trend in rents in Austria. Also, in many countries, rents computed using the fixed effect estimators are smaller than the random effects ones, as expected.

When we look at the average rent, a few strange phenomena arise, like the quasi-disappearence of the average rent in France, Spain, and Italy. Again, it seems highly volatile, but there is still a downward trend in Austria.

\begin{tabular}{llllllll}
\hline \hline Country/Yr & 94 & 95 & 96 & 97 & 98 & 99 & 2000 \\
\hline Germany & 0.18 & 0.21 & 0.23 & & & & \\
Denmark & 0.16 & 0.17 & 0.15 & 0.22 & 0.21 & 0.18 & 0.21 \\
Netherlands & 0.12 & 0.17 & 0.31 & 0.06 & 0.41 & 0.18 & 0.20 \\
Belgium & 0.1 & 0.05 & 0.13 & 0.08 & 0.1 & & \\
France & 0.06 & 0.05 & 0.09 & 0.07 & 0.09 & 0.07 & 0.08 \\
United Kingdom & 0.32 & 0.19 & 0.18 & & & & \\
Ireland & 0.28 & 0.22 & 0.19 & 0.22 & 0.3 & 0.47 & 0.37 \\
Italy & 0.08 & 0.07 & 0.09 & 0.07 & 0.06 & 0.07 & 0.06 \\
Spain & 0.06 & 0.05 & 0.04 & 0.07 & 0.08 & 0.08 & 0.1 \\
Portugal & 0.07 & 0.06 & 0.1 & 0.06 & 0.07 & 0.1 & 0.11 \\
Austria & & 0.31 & 0.21 & 0.15 & 0.23 & 0.19 & 0.08 \\
Finland & & & 0.14 & 0.08 & 0.13 & 0.06 & 0.09 \\
\hline Table 5
\end{tabular}

Table 5 - Evolution of ARENT, fixed effects.

To conclude, there is no country for which we find a clear trend. There is mild evidence of falling rents in Austria and Ireland, but it is not robust across estimators. If one had to choose one's preferred estiamtion, however, I would opt for that of Table 3, which is based on the least volatile estimates of the inter-industry dummies. That table suggests a sharp drop of rents in Ireland but not elsewhere.

\subsection{Size effects}

While inter-industry wage differentials have been the most widely documented and dicussed phenomenon, one may also want to look at wage differentizals in other dimensions. Hence, we have also looked at the results one gets if instead of partitioning by industries one partitions by size categories. 
Instead of the industry dummies, we have added two size dummies for the regression, corresponding to three size categories: less than 100 employees, 100-500 employees, and more than 500 employees. The results look somewhat more plausible and of better quality than those obtained when looking at inter-industry differences, but unfortunately do not confirm them. They suggest that rents seem to be declining in Belgium, France, the U.K., Ireland, Italy (mildly) and Portugal, while they seem to be going up in the Netherlands and Spain, two countries where unemployment has actually fallen over the period! In other countries, they are stable. Thus, the only country for which these estimates recoup those of the previous section is Ireland.

\begin{tabular}{llllllll}
\hline \hline Country/Yr & 94 & 95 & 96 & 97 & 98 & 99 & 2000 \\
\hline Germany & 0.24 & 0.25 & 0.26 & & & & \\
Denmark & 0.07 & 0.08 & 0.09 & 0.08 & 0.09 & 0.06 & 0.08 \\
Netherlands & 0.07 & 0.07 & 0.08 & 0.1 & 0.09 & 0.12 & 0.1 \\
Belgium & 0.11 & 0.12 & 0.12 & 0.12 & 0.12 & 0.09 & 0.06 \\
France & 0.2 & 0.22 & 0.22 & 0.25 & 0.24 & 0.18 & 0.16 \\
United Kingdom & 0.16 & 0.13 & 0.12 & & & & \\
Ireland & 0.24 & 0.2 & 0.21 & 0.16 & 0.15 & 0.10 & 0.13 \\
Italy & 0.09 & 0.09 & 0.08 & 0.08 & 0.08 & 0.08 & 0.06 \\
Spain & 0.11 & 0.15 & 0.15 & 0.14 & 0.16 & 0.14 & 0.17 \\
Portugal & 0.12 & 0.10 & 0.14 & 0.11 & 0.09 & 0.08 & 0.07 \\
Austria & & 0.1 & 0.08 & 0.06 & 0.08 & 0.1 & 0.09 \\
Finland & & \multicolumn{7}{c}{0.08} & 0.1 & 0.09 & 0.09 & 0.12 \\
\hline Table 5- Evolution of SPREAD, Size differentials \\
\hline \multicolumn{7}{l}{ SPR }
\end{tabular}




\begin{tabular}{llllllll}
\hline \hline Country/Yr & 94 & 95 & 96 & 97 & 98 & 99 & 2000 \\
\hline Germany & 0.08 & 0.08 & 0.08 & & & & \\
Denmark & 0.03 & 0.02 & 0.02 & 0.02 & 0.02 & 0.02 & 0.02 \\
Netherlands & 0.03 & 0.03 & 0.03 & 0.04 & 0.04 & 0.05 & 0.04 \\
Belgium & 0.05 & 0.05 & 0.05 & 0.04 & 0.05 & 0.03 & 0.01 \\
France & 0.06 & 0.07 & 0.07 & 0.04 & 0.05 & 0.04 & 0.03 \\
United Kingdom & 0.1 & 0.07 & 0.06 & & & & \\
Ireland & 0.07 & 0.06 & 0.06 & 0.03 & 0.03 & 0.02 & 0.03 \\
Italy & 0.02 & 0.02 & 0.02 & 0.01 & 0.01 & 0.01 & 0.01 \\
Spain & 0.03 & 0.01 & 0.03 & 0.03 & 0.03 & 0.03 & 0.03 \\
Portugal & 0.01 & 0.01 & 0.02 & 0.01 & 0.01 & 0.01 & 0.01 \\
Austria & & 0.03 & 0.02 & 0.02 & 0.02 & 0.02 & 0.02 \\
Finland & & & 0.02 & 0.02 & 0.02 & 0.02 & 0.03 \\
\hline \hline
\end{tabular}

Table 6 - Evolution of ARENT, Size differentials.

To conclude, the inter-industry approach does not suggest a systematic pattern of falling rents in Europe. When it does for some country, it does not seem to be related to any fall in unemployment in the corresponding country. Finally, the results are different when one breaks down industries by sector of activity or firm size. The only confident inference, if any, that one may make from the exercise is that rents have fallen in Ireland.

One potential problem with the approach is that labor market liberalization may have conflicting effects on our estimated rents. On the one hand, it eliminates pure rents that are not the return to productive ability, on the other hand, by getting rid of wage compression indued by regulation and collective bargaining, it may widen wage differentials by increasing the return to unobserved ability, match-specific human capital, and so on; if these factors are more present in some industries than others then measured interindustry differences may well widen. Even a fixed effect estimator would not solve that problem: a given individual will earn different returns in different years if these years are associated with a different regulatory environment..

Our provisional conclusion, however, is that there is no firm ground to believe that European labor markets have generally become more competitive in the 1990s on the basis of these estimates. 


\section{Results II: The transition approach}

We now report the results of the transition approach to measuring rents. Unfortunately, they are not much more conclusive than the previous one, in part due to data problems. When the first technique, consisting in using actual income data to estimate unemployment benefits, is used, one gets an unplausibly large increase in benefiots in belgium. When the second technique is used, its implied evolution for replacement ratios do not match that of the first technique. Furthermore, it tends to predict a large fall in rents for Italy, because unemploymentr benefits were made much more generous in the 1990s. However, such an increase in benefit payments is not observed in the data. Therefore, the results are quite sensitive to the way changes in benefits are measured.

\begin{tabular}{lllll}
\hline \hline Country & \multicolumn{2}{l}{ Non adjusted } & Adjusted \\
\hline & $\Delta Q / Q$ & $\Delta q / q$ & $\Delta Q / Q$ & $\Delta q / q$ \\
Denmark & +0.045 & -0.045 & -0.023 & -0.11 \\
Belgium & -0.045 & 0.149 & -0.113 & +0.08 \\
France & +0.048 & -0.058 & -0.011 & -0.11 \\
Ireland & +0.0956 & 0.194 & -0.084 & 0.0144 \\
Italy & +0.05 & +0.0 & -0.01 & -0.06 \\
Spain & +0.112 & +0.146 & +0.0226 & +0.0563 \\
Portugal & +0.133 & +0.081 & +0.0258 & -0.0256 \\
Austria & +0.0139 & -0.02 & -0.058 & -0.09 \\
Finland & -0.01 & -0.189 & -0.087 & -0.267 \\
\hline \hline
\end{tabular}

Table 7. The transition approach

Table 7 reports the evolution of measured rents for four alternative measures. The unadjusted rents are the ones defined in section 3.2. The adjusted ones deflate the adjusted ones to allow for growth (It subtracts the expected difference in GDP between the two subperiods on the basis of average GDP growth between 1980 and 2000). If the rents grow less fast than the economy, in the long-run they eventually account for a negligible fraction of labor costs and the economy converges toward a competitive labor market. Thus the last two columns express rents relative to GDP, while the first two columns ex- 
press them in real consumption units.

A first aspect of the results is that they are not very robust: rents are quite sensitive to whether growth is allowed for or not, and the evolution of the total rent $Q$ often diverges from that of the rent per unit of time, suggesting that changes in the separation rate $s$ play a quantitatively important role in the results (as an increase in $s$, all else equal, reduces $Q$ but increases $q$. Relatedly, the evolution of rents is again not much related to that of unemployment over the period. However, the adjusted $\Delta Q / Q$, does a better job than the other measures, as its correlation with the change in unemployment is 0.3. Thus it has some claim to be the most preferred measure. On that basis, the conclusion suggested by these estimated is more optimistic than that of the inter-industry approach: rents fall significantly in four countries: Ireland, Belgium, Austria and Finland, and they fall moderately in three other countries: Denmark, Italy and France.

\section{Conclusion}

This paper has tried to provide some quantitative evidence on the evolution of labor market competition in Europe in the 1990s, based on various estimates of labor market rents. The results are rather inconclusive, probably due to the quality of the data. A general conclusion is that there is no strong evidence that labor markets have become either more or less competitive in any European country over that period. One exception seems to be Ireland, thoughy, for which a number of estimated rents fall significantly over the period. 


\section{REFERENCES}

Bertola, Giuseppe, "Job Security, Employment and Wages " European Economic Review 34, 4 (June 1990): 851-79

Blanchard, Olivier and Thomas Philippon (2003), "The decline of rents, and the rise and fall of European unemployment", mimeo, MIT

Blanchard, Olivier, and Summers (1986), "Hysteresis and the European Unemployment Problem", NBER Macroeconomics Annual

Caballero, Ricardo and Mohammad Hammour (1998), "The Macroeconomics of Specificity", Journal of Political Economy 106, 4 (August 1998): 724-67

Cohen, Daniel (1999), "Welfare Differentials Across French and US Labour Markets: A General Equilibrium Interpretation", Centre for Economic Policy Research Discussion Paper: 2114

Grubb, David and William Wells (1993), "Employment Regulation and Patterns of Work in EC Countries", OECD Economic Studies 0, 21: 7-58

Krueger, Alan and Lawrence Summers (1988), "Efficiency Wages and the Inter-industry Wage Structure", Econometrica 56, 2: 259-93

Layard, Richard, Steven Nickell, and Richard Jackman (1990), Unemployment. Oxford: Oxford U. Press

Lindbeck, Assar; Snower, Dennis J (1988), The insider-outsider theory of employment and unemployment, Cambridge, Mass. and London: MIT Press.

Mortensen, Dale, and Christopher Pissarides (1994), "Job Creation and Job Destruction in the Theory of Unemployment ", Review of Economic Studies 61, 3: 397-415

Nickell, Steven (2003), "Labour market institutions and unemployment in OECD countries" CES-Ifo DICE Report, 2, 2003.

OECD, (1994), OECD Jobs Study, Paris, OECD

Saint-Paul, Gilles (1996a), "Voting for Jobs: Policy Persistence and Unemployment", Centre for Economic Policy Research, Discussion Paper: 1428 - (1996b), Dual labor markets: a macroeconomic perspective, MIT Press 
- (1997), "The rise and persistence of rigidities", American

Economic Review, May

- (2000), The political economy of labour market institutions. Oxford: Oxford University Press

- (2002), "The political economy of employment protection", Journal of Political Economy

Shapiro, Carl, and Joseph Stiglitz (1984), "Equilibrium Unemployment as a Worker Discipline Device", American Economic Review 74, 3 : 433-44

Schlicht, Ekehart (1978), "Labour Turnover, Wage Structure and Natural Unemployment", Zeitschrift fur die gesamte Staatswissenschaft (JITE) 134, $2: 337-46$

Solow, Robert (1979), "Another Possible Source of Wage Stickiness", Journal of Macroeconomics 1, 1 : 79-82 